\title{
PENCEGAHAN KEMATIAN MASAL BENIH IKAN MAS (Cyprinus carpio) AKIBAT BAKTERI (Pseudomonas fluorescent) DENGAN DAUN BELUNTAS (Pluchea indica)
}

\author{
As'ad Syamsul Arifin ${ }^{1}$ \\ IKIP Budi Utomo, Jl. Arjuno No. 46, Malang \\ e-mail: asad.ilem@yahoo.com
}

\begin{abstract}
Pseudomonas fluorescent jenis bakteri bersifat patogen dan dapat menyebabkan serangan sistemik serta mengakibatkan kematian secara masal. Bakteri ini menginfeksi luka dan menyebabkan kematian setelah satu minggu ikan mas terinfeksi. Pengobatan dalam penelitian ini menggunakan filtrat daun beluntas, selama ini daun beluntas hanya digunakan sebagai sayuran dan pagar di tepi jalan. Penelitian ini dilakukan dengan metode penelitian true eksperimen melalui pendekatan The Post Test Only Control Group Design. Variabel dalam penelitian ini antara lain variabel bebas, konsentrasi filtrat daun beluntas yang terdiri dari $0 \%$, $2.5 \%, 3.5 \%, 4.5 \%$. Variabel terikat, tingkat kelangsungan hidup benih ikan mas yang terinfeksi bakteri Pseudomonas fluorescent. Variabel kontrol antara lain suhu, $\mathrm{pH}$ netral, DO meter, ppm, volume air, pakan, dan usia ikan. Analisis data dilakukan dengan uji pendahuluan, yaitu uji normalitas dan uji homogenitas, dilanjutkan dengan uji hipotesis anava satu arah. Hasil penelitian ini menunjukkan bahwa pengobatan tradisional menggunakan daun beluntas yang paling efektif terhadap benih ikan mas yang terinfeksi bakteri Pseudomonas flourescent adalah konsentrasi 3,5\%, yang menunjukkan kelangsungan hidup tertinggi.
\end{abstract}

\section{Keywords: Glycine max (L.), Infeksi Cowpea Mild Mottle Virus (CPMMV)}

\section{PENDAHULUAN}

Ikan mas adalah jenis ikan air tawar yang banyak digemari dikalangan petani maupun masyarakat. Ikan mas telah lama dikenal dan disukai (dikonsumsi), sehingga pemasarannya tidak sulit. Ikan mas memiliki beberapa keunggulan antara lain ikan mas mudah dikembangbiakkan dengan cara membuat manipulasi lingkungan, selain itu dengan menggunakan kawin suntik (hipofisasi) (Khairuman, 2002).

Mengingat sangat banyak permintaan konsumsi terhadap ikan mas, maka usaha tersebut berkembang kearah intensif. Budidaya ikan secara intensif ditandai dengan padat penebaran yang tinggi dan pemberian pakan buatan dengan tujuan memproduksi hasil perikanan dalam jumlah yang maksimal. Semakin tinggi berkembangnya usaha budidaya, maka banyak pula kendala yang harus dihadapi. Salah satu diantaranya adalah yang berkaitan dengan penyakit dan kesehatan ikan yang dibudidayakan (Prajitno, 2003).

Masalah hama dan penyakit pada usaha budidaya ikan merupakan kendala yang serius karena menyebabkan tingkat kematian yang tinggi, terutama selama fase benih (Jangkaru, 2000). Umumnya penyakit yang sering dijumpai pada benih ikan mas adalah akibat dari serangan bakteri. Ada beberapa jenis bakteri yang dapat meningkatkan kematian benih antara lain Aeromonas dan Pseudomonas flourescent, serta parasit Argulus. Wabah serangan bakteri Pseudomonas fluorescent pernah terjadi 
bulan Oktober 1980, terutama di daerah Jawa Barat dan sekitarnya. Kerugian yang ditimbulkan sangat besar, sebab dalam waktu relatif singkat puluhan ton ikan mati secara masal, baik ukuran kecil maupun induk (Alfianto, 1992).

Pseudomonas fluorescent adalah jenis bakteri bersifat patogen dan dapat menyebabkan serangan sistemik serta mengakibatkan kematian secara masal. Bakteri ini menginfeksi luka dan menyebabkan kematian setelah satu minggu ikan mas terinfeksi. Selain menginfeksi luka bakteri ini dapat ditemukan di hati dan ginjal (Jangkaru, 2004).

Selama ini pengendalian bakteri menggunakan obat antibiotik melalui penyuntikan, proses perendaman, atau dicampur dengan pakan, bahan kimia antibiotik yang dapat digunakan antara lain Chloramphenicol, Oxytetracyclin dan Streptomicin (Zulkifli, 2000). Alternatif lain untuk pengobatan penyakit ini adalah dengan memanfaatkan obat-obatan dari alam yang mengandung zat antimikroba. Kandungan zat antimikroba dapat menghambat pertumbuhan dan memusnahkan mikroorganisme (Arief, 2003).

Tanaman obat tradisional daun beluntas telah lama dimanfaatkan oleh manusia akan tetapi pemanfaatan untuk jenis hewan masih belum berkembang dan sepopuler penggunaan pada manusia. Tanaman yang telah lama diketahui oleh masyarakat Indonesia, yaitu tanaman beluntas (Pluchea indica). Tanaman daun beluntas sering dijadikan tanaman pagar di beberapa halaman rumah penduduk. Daun beluntas secara teori dan tradisional berkhasiat dapat menurunkan gejala demam, menambah atau meningkatkan selera nafsu makan, bahaya peluruh keringat, dan penyegar aroma badan (Dalimartha, 1999). Informasi terdahulu daun beluntas dikabarkan oleh Purnomo pada tahun 2001, khasiat antimikroba pada daun beluntas diperoleh dari kandungan minyak atsiri, tannin, alkaloid, dan flavonoid (Hariana, 2006).

Menurut Pelezer dan Chan (1986), tanaman beluntas bersifat bakterisid dan bakteriostatik. Kandungan utama beluntas adalah tannin yang dapat menghambat pertumbuhan dan memusnahkan mikroorganisme. Daya kerja obat yang baik akan dipengaruhi oleh dosis, jenis zat yang dikandungnya, lama pengobatan dan tidak menimbulkan kematian bagi hospesnya.

\section{METODE PENELITIAN}

Penelitian ini dilakukan dengan metode penelitian true eksperimen melalui pendekatan The Post Test Only Control Group Design. Penelitian ini dilakukan di tempat Laboratorium Universitas Muhammadiyah Malang. Sampel yang digunakan dalam penelitian ini adalah 200 ekor benih ikan mas, yang sengaja diambil di Laboratorium Balai Benih Ikan yang berada di Punten, Jl Mawar Putih No 86 di Desa Sidomulyo Kecamatan Kota Batu, Jawa Timur, yang berumur 2 bulan dengan ukuran panjang tubuh $5-7 \mathrm{~cm}$.

Variabel yang sengaja dipilih atau diubah oleh peneliti untuk dipelajari pengaruhnya adalah variabel bebas yaitu konsentrasi filtrat daun beluntas yang terdiri dari $0 \%, 2.5 \%, 3.5 \%, 4.5 \%, 5.5 \%$. Variabel terikat yaitu tingkat kelangsungan hidup benih ikan mas yang terinfeksi bakteri Pseudomomas flourecent. Variabel kontrol dalam penelitian ini antara lain suhu, 24$28^{0} \mathrm{C}$, pH netral 6,5-7,5, DO meter > $3 \mathrm{ppm}$, volume air 1 liter, pakan pelet 2 kali sehari, dan usia ikan 2 bulan.

Subyek yang diambil adalah populasi dikelompokkan secara random (acak) dengan 5 perlakuan A, B, C, D, dan E, kemudian 4 
kali ulangan, sehingga jumlah sampel yang dapat dilihat pada Tabel 1 berikut ini: diamati sebanyak 20 buah. Denah penelitian

Tabel 1. Persentase Konsentrasi Filtrat Daun Beluntas Tiap Ulangan

Keterangan:

\begin{tabular}{llll}
\hline A1 & B1 & C3 & A4 \\
\hline B2 & C1 & D1 & E2 \\
A2 & D4 & D3 & A3 \\
B3 & E3 & B4 & D2 \\
E1 & C2 & E4 & C4 \\
\hline
\end{tabular}

A1: Konsentrasi filtrat daun beluntas $0 \%$ ulangan 1.

A2: Konsentrasi filtrat daun beluntas $0 \%$ ulangan 2 .

A3: Konsentrasi filtrat daun beluntas $0 \%$ ulangan 3 .

A4: Konsentrasi filtrat daun beluntas $0 \%$ ulangan 4.

B1: Konsentrasi filtrat daun beluntas $2.5 \%$ ulangan 1 .

B2: Konsentrasi filtrat daun beluntas $2.5 \%$ ulangan 2 .

B3: Konsentrasi filtrat daun beluntas $2.5 \%$ ulangan 3 .

B4: Konsentrasi filtrat daun beluntas $2.5 \%$ ulangan 4 .

$\mathrm{C} 1$ : Konsentrasi filtrat daun beluntas $3.5 \%$ ulangan 1 .

C2: Konsentrasi filtrat daun beluntas $3.5 \%$ ulangan 2 .

Dasar penentuan membuat obat filtrat daun beluntas menurut Daelami (2002), yang menyatakan bila obat berbentuk cairan atau emulsion maka perhitungannya menggunakan rumus sebagai berikut:

$$
\mathrm{V}_{1} \times \mathrm{C}_{1}=\mathrm{V}_{2} \times \mathrm{C}_{2}
$$

Keterangan:

$\mathrm{V}_{1}$ : volume obat yang dibutuhkan,

$\mathrm{C}_{1}$ : konsentrasi obat,

$\mathrm{V}_{2}$ : volume air kolam,

$\mathrm{C}_{2}$ : dosis pengobatan.

Analisis data dilakukan dengan uji pendahuluan, yaitu uji normalitas dan uji homogenitas, jika data normal dan homogen maka dilanjutkan dengan anava satu arah, dengan asumsi jika $\mathrm{t}$ hitung $>\mathrm{F}$ tabel maka dilanjutkan dengan uji lanjut duncan.

\section{HASIL DAN PEMBAHASAN}

Data di atas menunjukkan bahwa penggunaan filtrat daun beluntas dalam bakbak perlakuan dengan konsentrasi perlakuan yang berbeda-beda pada benih ikan mas berukuran $5-7 \mathrm{~cm}$ yang terserang bakteri Pseudomonas flourescent menghasilkan
C3: Konsentrasi filtrat daun beluntas 3.5\% ulangan 3 . C4: Konsentrasi filtrat daun beluntas $3.5 \%$ ulangan 4 .

D1: Konsentrasi filtrat daun beluntas $4.5 \%$ ulangan 1 . D2: Konsentrasi filtrat daun beluntas $4.5 \%$ ulangan 2 .

D3: Konsentrasi filtrat daun beluntas $4.5 \%$ ulangan 3 .

D4: Konsentrasi filtrat daun beluntas $4.5 \%$ ulangan 4 .

E1: Konsentrasi filtrat daun beluntas $5.5 \%$ ulangan 1. E2: Konsentrasi filtrat daun beluntas 5.5\% ulangan 2 .

E3: Konsentrasi filtrat daun beluntas $5.5 \%$ ulangan 3 .

E4: Konsentrasi filtrat daun beluntas 5.5\% ulangan 4 .

kelangsungan hidup yang berbeda-beda. Hasil perhitungan data kelangsungan benih ikan mas pada masing-masing perlakuan yaitu perlakuan A $(0 \%)$ dengan rata-rata $0 \%$, perlakuan $\mathrm{B}(2,5 \%)$ dengan rata-rata $4,25 \%$, perlakuan $\mathrm{C}(3,5 \%)$ dengan rata-rata $7,75 \%$, perlakuan $\mathrm{D}(4,5 \%)$ dengan rata-rata $5 \%$, dan perlakuan E $(5,5 \%)$ dengan rata-rata $9,04 \%$.

Berdasarkan hasil perhitungan Anava satu arah mendapatkan hasil bahwa pemberian filtrat daun beluntas dengan konsentrasi yang berbeda memberikan pengaruh nyata terhadap tingkat kelangsungan hidup benih ikan mas yang terinfeksi bakteri Pseudomonas flourescent.

Hasil penelitian menunjukkan bahwa filtrat daun beluntas berpengaruh terhadap tingkat kelangsungan hidup benih ikan yang terinfeksi bakteri. Sumber terdahulu menjelaskan ekstrak etanol daun beluntas dengan menggunakan berbagai konsentrasi $25 \%, \quad 50 \%, \quad 75 \%$ dan $100 \%$ dapat menghambat proses pertumbuhan jenis bakteri Pseudomonas flourescent, dengan konsentrasi minimal yang dapat menghambat 
pertumbuhan bakteri adalah $25 \%$, Nahak $1,593 \mathrm{~cm}$ terhadap jenis bakteri

Konsentrasi larutan dalam penelitian yang dilakukan oleh Ratna (2013), menggunakan konsentrasi 12\%, 24\%, 36\%, $48 \%$ dan $60 \%$ untuk setiap jenis bakteri. Hasil penelitian menunjukkan ekstrak etanol daun beluntas memberikan diameter daya hambat berbeda-beda diantaranya 1,203-
Staphylococcus aureus; $1,051-1,430 \quad \mathrm{~cm}$ terhadap jenis bakteri Bacillus subtilis; dan 1,143- $1,525 \mathrm{~cm}$ terhadap jenis bakteri Pseudomonas aeruginosa.

Hasil dalam penelitian ini Konsentrasi yang paling berpengaruh dapat dilihat pada Tabel 2 di bawah:

Tabel 2. Hasil Uji Duncan pada Berbagai Perlakuan

\begin{tabular}{cccc}
\hline No & Perlakuan & Rerata & Notasi \\
\hline 1 & $\mathrm{~B}(2.5 \%)$ & 4,25 & $\mathrm{a}$ \\
\hline 2 & $\mathrm{C}(3.5 \%)$ & 7,75 & $\mathrm{~b}$ \\
\hline 3 & $\mathrm{D}(4.5 \%)$ & 5 & $\mathrm{~b}$ \\
\hline 4 & $\mathrm{E}(5.5 \%)$ & 3,5 & $\mathrm{~b}$ \\
\hline
\end{tabular}

Berdasarkan notasi di atas dapat dijelaskan bahwa perlakuan B 2,5\% dengan rerata 4,25 , perlakuan $C 3,5 \%$ dengan rerata 7,75 , perlakuan D $4,5 \%$ dengan rerata 5 , dan perlakuan E 5,5\% dengan rerata 3,5. Hasil uji Duncans perlakuan C 3,5\% dengan rerata 7,75 memberikan hasil kelangsungan hidup tertinggi namun tidak memberikan pengaruh nyata jika dibandingkan dengan perlakuan $\mathrm{O}$ dan E. Perlakuan C menghasilkan kelangsungan hidup tertinggi, hal ini disebabkan karena filtrat daun beluntas yang telah diberikan kepada ikan mas yang terinfeksi bekteri Pseudomonas fluorescent mampu membunuh pertumbuhan bakteri di dalam tubuh ikan mas. Syafi'I (2006) menjelaskan ini disebabkan karena konsentrasi yang paling efektif kandungan tannin sebagai bahan aktif bisa dimanfaatkan sebagai obat, karena daya kerja obat yang baik akan dipengaruhi oleh konsentrasi dan jenis zat yang dikandung.

Perlakuan D yaitu dengan menghasilkan kelangsungan hidup yang rendah, hal ini disebabkan karena filtrat daun beluntas yang diberikan kepada ikan mas melebihi konsentrasi yang dibutuhkan, sehingga memberikan efek yang membahayakan. Peperna
(1980) menjelaskan jika penggunaan filtrat di atas ambang batas dapat menyebabkan keberadaan lendir pada ikan, sehingga semakin lama lendir akan hilang dan ikan mengalami kematian.

Selanjutnya perlakuan E dengan menghasilkan kelangsungan hidup lebih rendah jika dibandingkan dengan perlakuan $\mathrm{D}$, hal ini disebabkan karena filtrat daun beluntas yang diberikan terhadap ikan mas melebihi konsentrasi yang dibutuhkan oleh ikan mas, sehingga memberikan efek yang membahayakan. Syafi'I (2006) menjelaskan karena disebabkan dosis yang tinggi (kandungan bahan aktifnya semakin tinggi) akan lebih dominan terabsorbsi oleh ikan karena adanya perbedaan tekanan antara tubuh ikan dengan lingkungan luar sehingga tannin masuk ke tubuh ikan melalui dinding sel dan mengganggu sintesa protein, kemudian akan terjadi denaturasi atau penghancuran protein pada ikan yang dapat menghambat kelangsungan hidup ikan, maka ikan percobaan mengalami kematian.

\section{SIMPULAN DAN SARAN}

Berdasarkan hasil pembahasan dapat disimpulkan bahwa pengobatan tradisional menggunakan daun beluntas yang paling efektif 
terhadap benih ikan mas yang terinfeksi bakteri Pseudomonas flourescent adalah perlakuan C dengan konsentrasi 3,5\%, dengan menghasilkan kelangsungan hiduup tertinggi.

Pada penelitian lanjutan perlu dilakukan penelitian atau uji coba pada ikan dan bakteri lain guna dapat mengetahui daya kerja obat yang terkandung pada daun.

\section{RUJUKAN}

Afrianto, E. 1992. Pengendalian Hama Penyakit pada Ikan. Penerbit: Kanisius. Yogyakarta.

Anshori, I. 2007. Penggunaan Filtrat Crude Daun Cengkeh untuk Pengobatan Ikan Gurami yang Terinfeksi Bakteri Aeromonas hydrophilla. Penerbit: UMM malang.

Dalimarta. 1999. Manfaat Daun Beluntas. Jurnal Internet.

Daelami, D. 2002. Agar Ikan Sehat. Penerbit: Penebar Swadaya. Jakarta.

Ghufran, Kordi. 2004. Hama dan Penyakit Ikan Kakap. Penerbit: Kanisius. Jakarta.

Hariana. 2006. Kandungan Daun Beluntas. Jurnal Internet.

Jangkaru, J. 2004. Memacu Pertumbuhan Gurami. Penerbit: Penebar Swadaya. Jakarta.
Khairuman, A. 2002. Pembesaran Ikan Mas di Kolam Air Deras. Penerbit: Agromedia Pustaka. Jakarta.

Nahak, M.M. 2012. Ekstrak etanol daun beluntas (Pluchea indica. L.) dapat menghambat pertumbuhan bakteri Streptococcus mutans. Denpasar.

Peperna, I. 1980. Parasites Infection and Disease of Fish in Africa. Food and Agricultur Organization of United Nation.

Prajitno. 2003. Pengobatan penyakit Aeromonas hydrophilla pada Benih Ikan Gurami Menggunakan Kunyit. Jurnal Penelitian Perikanan. Volume 6, Juni 2003, Hal 72.

Rofieq, A. 2002. Metodelogi Penelitian. Modul Mahasiswa Biologi. Universitas Muhammadiyah Malang.

Ratna, RS. 2013. Aktivitas Antibakteri Ekstrak Etanol Daun Beluntas. Jurnal Ilmiah, Universitas Surabaya, Vol 2 No.1.

Syafi'i, I. 2006. Pengaruh Penggunaan Serbuk Kunyit dan Lama Perendaman terhadap Kelulushidupan Benih ikan Mas yang terinfeksi Bakteri Aeromonas hydrophilla.

Zulkifli. 2000. Memacu Pertumbuhan Gurami. Penerbit: Penebar Swadaya. Jakarta. 